\title{
Pinus landsbergensis sp. nov., new pine from the Cenomanian of the Czech Republic
}

\author{
JIŘí KVAČEK
}

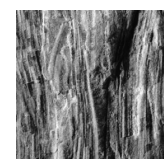

\begin{abstract}
Pinus landsbergensis J. Kvaček sp. nov. is described from the Bohemian Cretaceous Basin (Czech Republic). The material comes from localities Lanšperk and Pecínov. It shows characteristic fascicles of five needles born on a dwarf shoot. Its epidermis is built of elongate rectangular ordinary cells and monocyclic stomata forming rows. Similar Pinus species from the Cretaceous of USA and Japan are discussed. A conspiceous similarity is recorded between P. landsbergensis and $P$. quinquefolia from the Late Cretaceous of USA. $P$. landsbergensis is also compared to recent species of the subgenus Pinus. The most similar in epidermal characters are Central American pines P. montezumae and $P$. devonensis. Key words: Pinus, conifer, Cenomanian, Late Cretaceous, Bohemia.
\end{abstract}

KVAČEK, J. 2013. Pinus landsbergensis sp. nov., new pine from the Cenomanian of the Czech Republic. Bulletin of Geosciences 88(4), 829-836 (3 figures). Czech Geological Survey, Prague. ISSN 1214-1119. Manuscript received April 25, 2013; accepted in revised form September 6, 2013; published online October 21, 2013; issued October 31, 2013.

Jiři Kvaček, National Museum, Prague, Václavské nám. 68, 11579 Praha 1, Czech Republic; jiri.kvacek@nm.cz.

The Pinaceae is one of the youngest conifer families. History of the Pinaceae begins in Late Jurassic. The oldest representative of the family was recently described from the Late Jurassic of Scotland (Rothwell et al. 2012). First unequivocal species of Pinus is reported from the Early Cretaceous Speeton Clay of the Yorkshire coast by Ryberg et al. (2012). During Cretaceous pines rapidly evolved and during Tertiary become the second diversified genus of conifers (e.g. Axelrod 1986). There are known about 110 species of living pines, vast majority of them occurring in the Northern Hemisphere (Farjon 2005). All pines are characterized by typical construction of ovuliferous cones having always two seeds per cone scale, but what is really diagnostic for pines are their needle-like leaves arranged in fascicles. Each fascicle represents a dwarf shoot (brachyblast) which consists of scale leaves (sheaths of cataphylls) in the base of the dwarf shoot and standard needles occurring in apical part of the dwarf shoot. The needle-like leaves are arranged singly ( $P$. monophylla), but usually in two, three, four or five per fascicle. Monophyletic nature of the genus divided into two subgenera Pinus and Strobus was documented in number of studies (e.g. Farjon \& Styles 1997, Price et al. 1998, Liston et al. 1999, Lin et al. 2010). Pines are remarkably successful in adaptations to various environmental conditions (Farjon 2005). Particularly known is their adaptation to seasonal climate (Axelrod 1986).

The Peruc-Korycany Formation of the Bohemian Cretaceous Basin provides a fossil flora very rich in conifers. It is sometimes referred to as the Peruc Flora and is one of the classical and key Cretaceous floras in the world. The first major studies of conifers from the Peruc Flora were those of Velenovský $(1885,1887,1889)$. In more recent years, conifers have been studied by Knobloch \& J. Kvaček (1997), J. Kvaček (1992a, b, 1997, 2000a, b, 2003, 2007), Bosma et al. (2012), including descriptions of new and revisions of previously described taxa. Currently, more than 30 species of conifers have been identified in the Peruc Flora. The fossils are mainly preserved as impressions and compressions in consolidated sediments, in rare cases bearing reproductive organs attached to leafy twigs (Velenovský 1889; Velenovský \& Viniklář 1926, 1927a, b, 1929, 1931; J. Kvaček 1997, 2000a, b; Bosma et al. 2012). Several species of the genus Pinus are described from the Bohemian Cretaceous Basin. They are based primarily on ovuliferous cones preserved as impressions in sandstone (Pinus quenstedtii Heer 1869, P. protopicea Velenovský 1885, P. longissima Velenovský 1885, P. vysehorovicensis Velenovský \& Viniklář 1927a, and P. kettneri Velenovský \& Viniklár 1927b). There is also an ovuliferous cone assigned by Geinitz (1871-1875, pl. 67, fig. 2) to Pinus quenststedtii Heer and ovuliferous cone scale described as Pinus ettingshausenii Engelhardt (1891) both reported from the Cenomanian of the Saxonian part of the Bohemian Cretaceous Basin. Both specimens are impressions, with only limited details preserved.

Revision of the already described ovuliferous cones is not an easy task. This will require application of new non-destructive methodologies. However, even now it is 


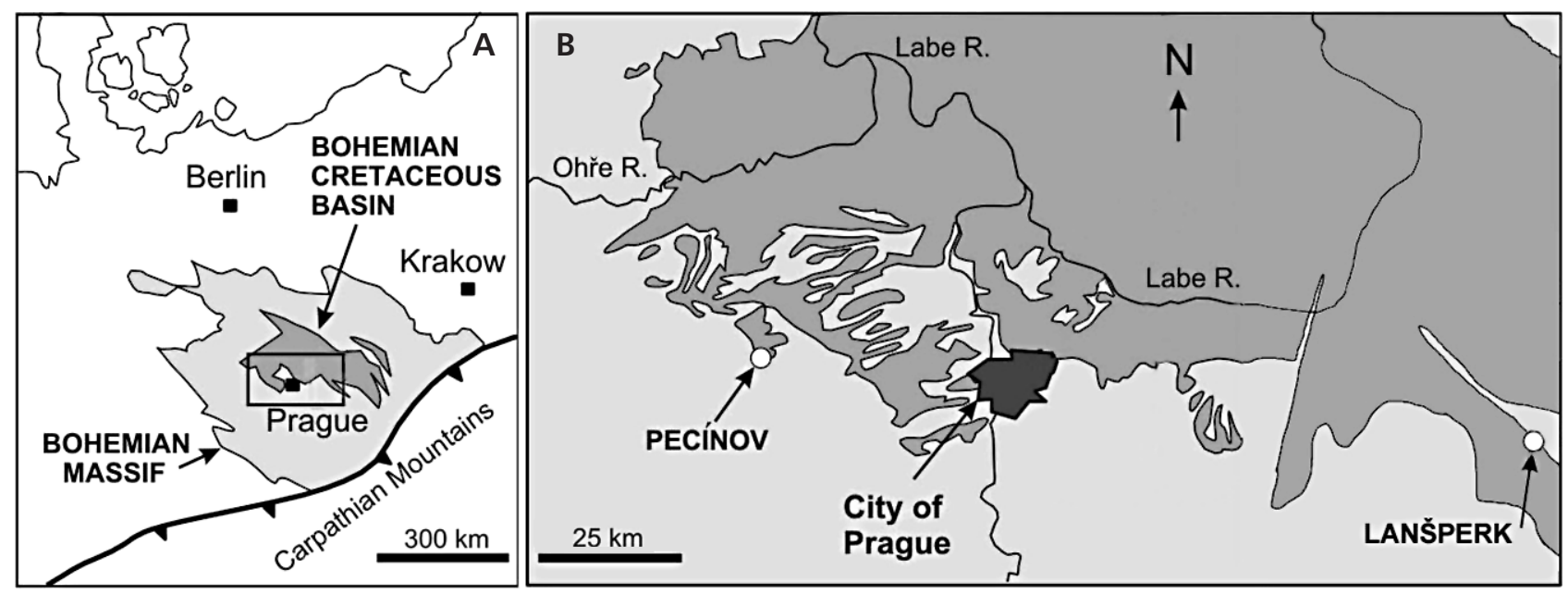

Figure 1. Geological setting. Location of the Bohemian Cretaceous Basin in Central Europe (left) and location of the two fossil sites mentioned in this paper. Dark grey area indicates Cretaceous Basin; light grey area indicates Bohemian Massif, R means river (reshaped after Uličný et al. 1997).

clear there are several species present based on ovuliferous cones, therefore it is expected that also sterile foliage will be diversified.

Several specimens of sterile foliage were described by Velenovský (1885) and Engelhardt (1891) and assigned to $P$. quenstedtii. Current revision however did not identify all of them as unequivocal pinaceous foliage. Some specimens described by Velenovský (1885, pl. 6, fig. 4) from the locality of Vyšehořovice and by Engelhardt (1891) from Niederschöna show affinity to the Pinaceae (long delicate leaves in one case forming doubtful dwarf shoot); however without knowledge of their cuticle or anatomy their systematic affinity remains equivocal. In the present paper new species of Cenomanian Pinus is described based on sterile foliage and its epidermal characters. It clearly distinguishes from all the already described taxa.

\section{Material and methods}

\section{Material}

The material consists of three hand specimens from Lanšperk (Landsberg) bearing leaf compressions or their fragments and one isolated charcoalified specimen from Pecínov. The locality Lanšperk is situated $4 \mathrm{~km}$ north east of Ústí nad Orlicí. The site was discovered by the Czech palae- ontologist Antonín Frič in 1866. It is situated 800 m south of the ruin of the Lanšperk castle in a deep forested valley (49 $9^{\circ} 9^{\prime} 18.316^{\prime \prime} \mathrm{N}, 16^{\circ} 27^{\prime} 8.422^{\prime \prime} \mathrm{E}$; Fig. 1). The layer of the dark mudstone $10 \mathrm{~cm}$ in thickness yielded number of leaf compressions of gymnosperm foliage and reproductive structures. Specimens have been collected there particularly by Antonín Frič, who hired number of workers. The site was intensively exploited and even now digging pit is still seen in the morphology of the valley. The material was worked out by Velenovský (1885). In 1995 the site has been newly rediscovered by the present author, but in poor state. The fossiliferous layer is not accessible. A registered spring arises just above the fossiliferous horizon.

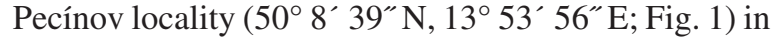
sense of Uličný et al. (1997) consists of several sedimentological units. Fossil remains of Pinus are found in the basalmost unit 1, interpreted by Uličný et al. (1997) as a small braided river.

The Bohemian Cretaceous Basin, as defined by Čech et al. (1980), located in the Bohemian Massif, Czech Republic, Central Europe (Fig. 1), is in-filled by Late Cretaceous freshwater, brackish and marine sediments of Cenomanian to Campanian age. The Peruc-Korycany Formation is situated in the most basal position of the Bohemian Cretaceous Basin. The detailed biostratigraphical studies based on pollen spectra (Pacltová 1977) date the Peruc-Korycany Formation to the upper part of the middle Cenomanian.

Figure 2. Pinus landsbergensis J. Kvaček sp. nov. • A - dwarf shoot from both sides showing details of sheaths of cataphylls (arrowed), Pecínov, F 3727, scale bar $500 \mu \mathrm{m}$. • B - fragments of numerous needles (basal parts of fascicles absent), Lanšperk; F 2533, scale bar 10 mm. • C - holotype, dwarf shoot bearing five needles, cataphyll arrowed, Lanšperk; F 2535, scale bar 7 mm. • D - light micrograph of cuticle of holotype showing stomatal rows (arrowed), phase contrast, Lanšperk; F 2533b, scale bar $100 \mu \mathrm{m}$. • E - light micrograph of cuticle of holotype showing stomatal rows, Lanšperk; F 2533c, scale bar $100 \mu \mathrm{m}$. • F - light micrograph of cuticle of holotype showing stomatal rows, phase contrast, Lanšperk; F 2533b, scale bar $100 \mu \mathrm{m}$. 

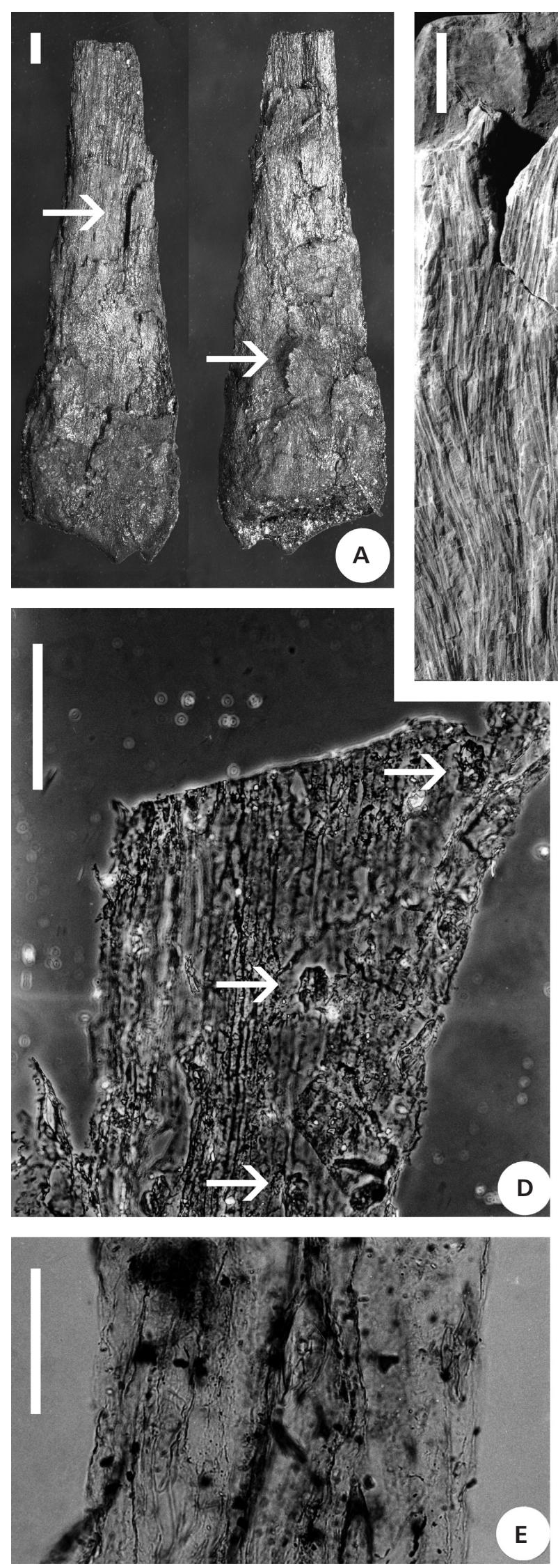
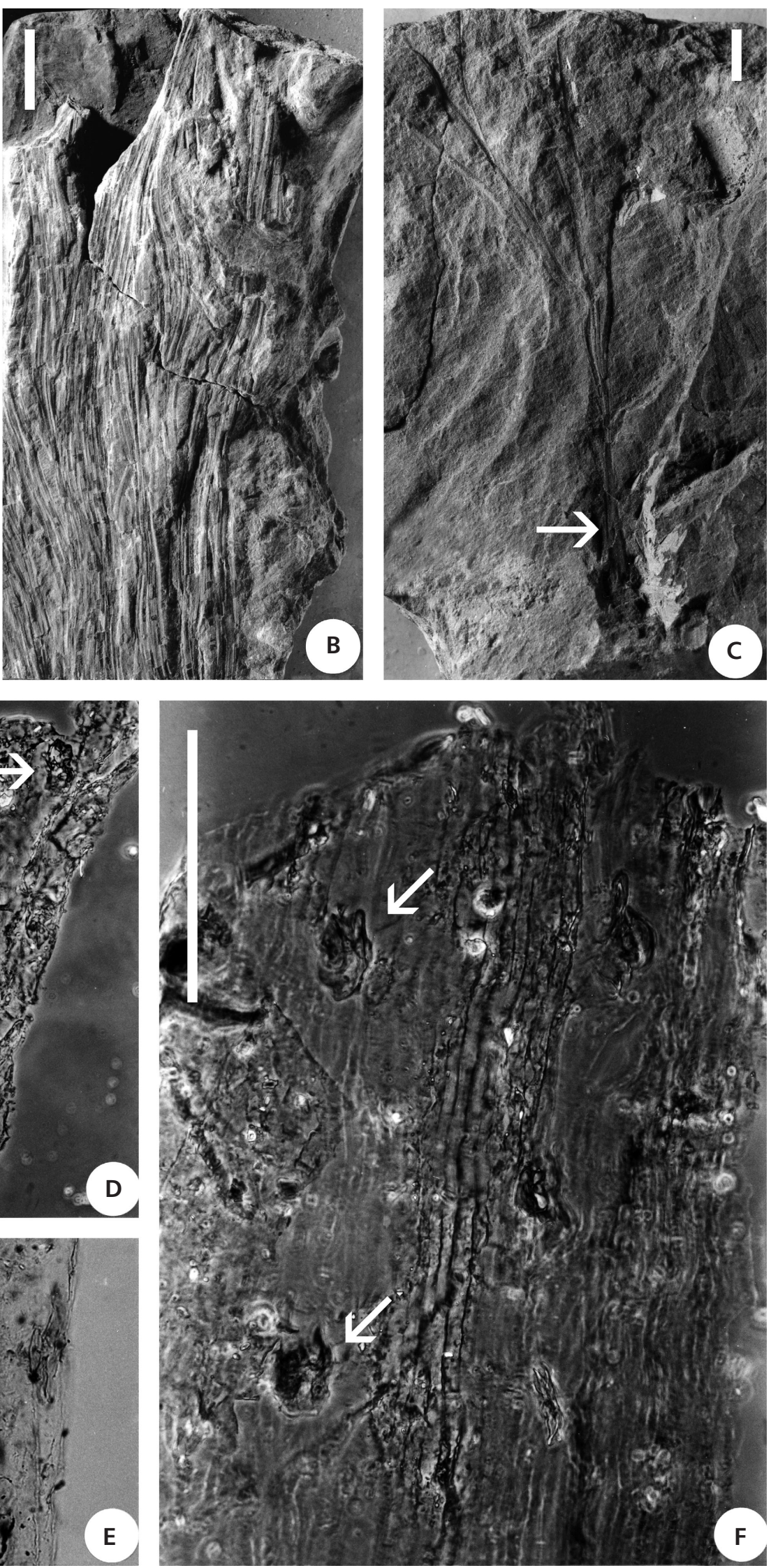


\section{Methods}

Pieces of carbonised material were carefully picked from the compressions with a preparation needle and treated for cuticle analysis. Carbonised material obtained by needle sampling was cleaned by treatment in HF. After cleaning, it was ready for a bleaching procedure that included maceration with Schulze's reagent: $\mathrm{HNO}_{3}+$ $\mathrm{KClO}_{3}$, neutralisation in water, and treatment in a low concentration solution of $\mathrm{KOH}$, which was used for washing out the oxidized coal matter. The time for oxidation was about 15 minutes. After chemical treatment, cuticles were washed in water in Petri dishes. For light microscopy, cuticles were embedded in glycerin framed by the Noyere framing cement. In most cases, preparations using needles under a binocular microscope were necessary to separate lower (abaxial) and upper (adaxial) cuticles and to adjust them properly on the preparation glass before covering.

The material from Pecínov, unit 1 is charcoalified. It was gathered by soaking in water and sieving through $0.125 \mathrm{~mm}$ sieve. Finally the material was cleaned in HF air dried and picked by a brush.

Cuticle preparations were studied by light microscopy using Phase Contast and Nomarski DIC methods by Olympus BX50; the mesofossil was observed using the digital microscope Keyence. All the studied material is housed in the National Museum, Prague (NMP).

\section{Systematic palaeobotany}

\section{Genus Pinus Linné, 1753}

Type. - Pinus sylvestris Linné, 1753, p. 1000.

\section{Pinus landsbergensis sp. nov.}

Figures 2A-F, 3A

Etymology. - From the German name of the locality - Landsberg.

Holotype. - F 2535 designated here (Fig. 2C-F).

Type locality. - Lanšperk (Landsberg).

Type horizon. - Cretaceous, Cenomanian, Peruc-Korycany Formation.
Diagnosis. - Needle-like leaves born in fascicles of five, in basal part attached to dwarf-shoot with helically arranged sheaths of cataphylls; leaves fan-shaped in transverse section, probably amphistomatic, ordinary cells elongate with nearly straight or slightly sinuous anticlinal walls, stomata in rows, sunken in heavily cutinized pits, monocyclic, surrounded by $6-8$ subsidiary cells. Between stomatal rows $10-11$ ordinary cells.

Material. - F 2533, F 2737, F 3726, F 3727.

Occurrence. - Lanšperk, Pecínov.

Description. - The holotype shows preserved needle-like leaves arranged in a fascicle of five (Fig. 2C). A basal part of the fascicle is $3 \mathrm{~mm}$ in diameter. The basal part of the dwarf-shoot bearing the fascicle shows several damaged helically arranged sheaths of cataphylls. The needles are triangular - fan-shaped, over $60 \mathrm{~mm}$ long and $0.5 \mathrm{~mm}$ broad. Another specimen, F 2533 from the same locality shows many large fragments of needle-like leaves over $100 \mathrm{~mm}$ long and $0.6 \mathrm{~mm}$ wide (Fig. 2B). Additional specimen F 3726 shows isolated leaf $43 \mathrm{~mm}$ long and $1 \mathrm{~mm}$ broad. The charcoalified specimen from Pecínov displays basal part of the dwarf shoot with numerous helically arranged sheaths of cataphylls (Fig. 2A).

The cuticle of the specimen F 2533 is very thin. Due to this fact observations were carried out by light-microscope in phase contrast or Nomarski DIC. The cuticle is probably amphistomatic. Ordinary cells are elongate [(4)-8-(22) $\times$ (15)-45-(100) $\mu \mathrm{m}]$, quadrangular with straight or slightly sinuous anticlinal walls (Fig. 2D-F). The "end wall shape" is perpendicular or oblique. Periclinal walls are granular. Stomata arranged in several rows (maximal number observed -4 rows per band), their axes are orientated parallel to the leaf margin (Fig. 2D, F). Stomata are sunken in heavily cutinized pits forming rectangular to polygonal asterisk-like structures [20-(30) $\times(35)-40-(50) \quad \mu \mathrm{m}$; Figs 2D-F, 3A]. Subsidiary cells are more isodiametric [(5)-10-(13) × (12)-25-(38) $\mu \mathrm{m}]$ usually four in polar position and four in lateral position. There are 10-11 ordinary cells between stomatal rows (Fig. 2D).

Remarks. - Leaf impressions described as Pinus quenstedtii by Velenovský (1885) from Vyšehorovice are interpreted here as a group of rather poorly preserved plant remains. The specimen figured by Velenovský (1885, pl. 6, fig. 4; F 256, F 702 - part and counterpart) shows a fragment

Figure 3. Pinus landsbergensis J. Kvaček sp. nov. • A - light micrograph of stoma showing rectangular to polygonal shape, holotype, Lanšperk; F 2533b, scale bar 50 m. • B - Pinus montezumae Lambert, Cuajimalpa, Mexico, specimen No. 8796, PR 560070, coll. NMP. • C - detail of stoma showing rectangular to polygonal shape, scale bar $50 \mu \mathrm{m}$. $\bullet \mathrm{D}$ - branch showing fascicles of needles with well dveloped sheaths of cataphylls, scale bar 50 mm. - E - ordinary cells between two stomatal rows, scale bar $100 \mu \mathrm{m}$. 

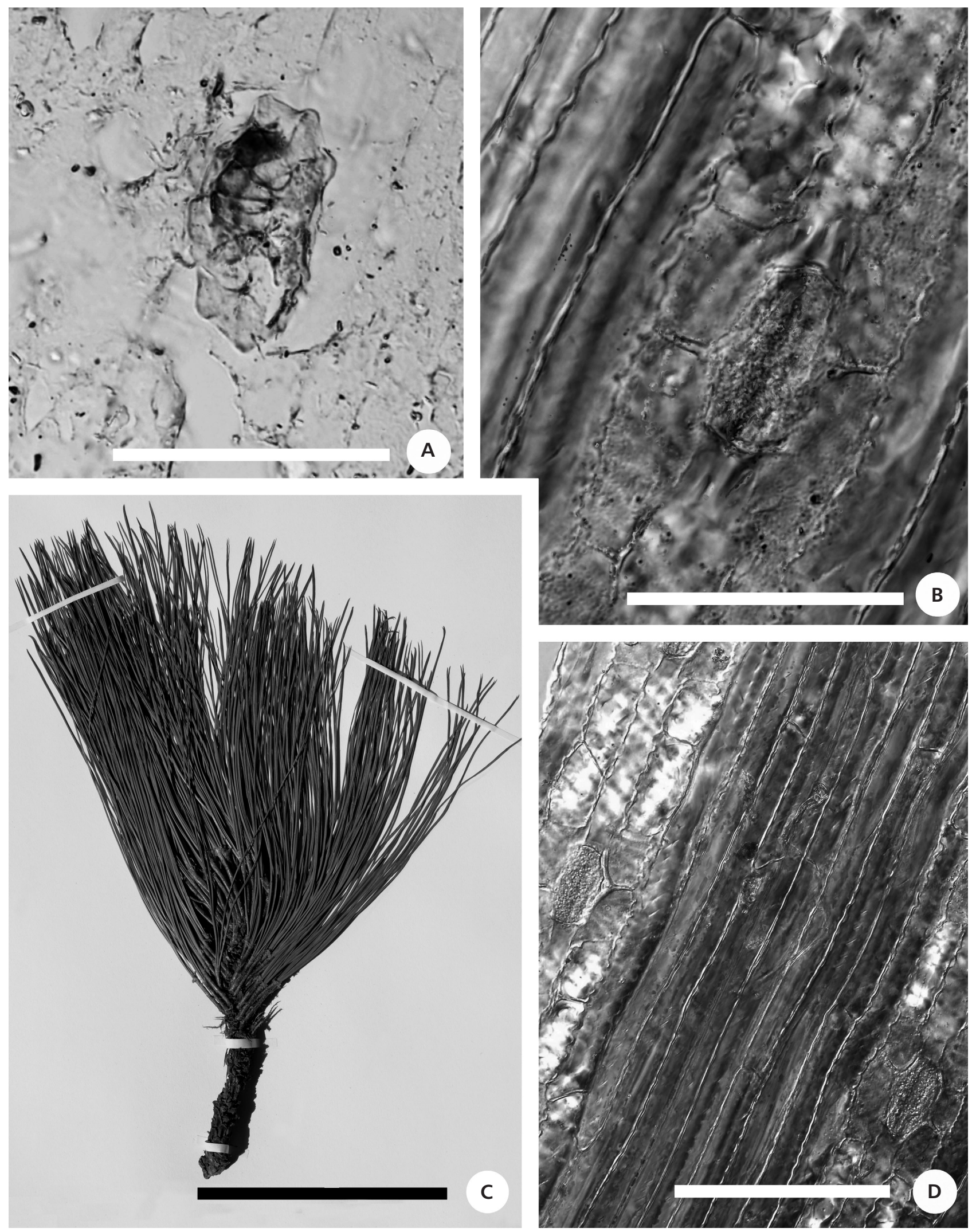
of pinaceous twig. Separate fascicles are difficult to observe, the best preserved ones show impressions of needles probably in fascicles of three. Their needles are over $60 \mathrm{~mm}$ and $0.6-1 \mathrm{~mm}$ broad. The specimen No. F 255 figured by Velenovský (1885, pl. 8, fig. 10) is rather poorly preserved. It has needles arranged probably in fascicles of two (or even arranged singly as depicted by Velenovský 1885). There is a serious doubt if it belongs to the genus $P i$ nus at all.

Additionally, there are two peculiar specimens, No. F 257 and No. F 2534, from Lanšperk in the collection of the National Museum, labeled by Velenovský as $P$. quenstedtii. However they do not show needles in fascicles of five. Their leaves are flat having medial vein and attached singly. Their cuticle shows adaxially two stomatal bands consisting of stomata of the Cupressaceae-type. These specimens do not belong to $P$. landsbergensis.

Discussion. - Pinus landsbergensis sp. nov. differs from earlier described pinaceous foliage interpreted by Velenovský (1885) as Pinus quenstedtii from the Bohemian Cretaceous Basin in having five leaves per fascicle. The leaves depicted by Velenovský (1885) are of two types. The first one, No. F 255 cannot be assigned to P. landsbergensis, due to poor preservation, lack of cuticle and having needles in two per fascicle. Two other specimens show leaves probably in fascicles of three. This material belongs to another fossil Pinus, however its preservation does not provide enough details for precise description.

Leaf impressions associated with Pinus quenstedtii from its type locality Starý Maletín are difficult to interpret. None of them shows leaves clearly arranged in fascicles. Careful inspection of the specimen figured and described by Heer (1869, pl. 2, fig. 5) revealed that the leaves were very long but they do not show arrangement or at least tendency to be arranged in fascicles. It is even possible that the twig could belong to some other conifer genus e.g. Cunninghamites of the Cupressaceae (compare van der Ham \& van Konijnenburg-van Cittert 2001, Bosma et al. 2012). Interestingly, also other long leaved conifer from the Peruc Flora coming from Lanšperk (specimen No. F 2534; J. Kvaček in prep.), shows epidermal characters which correspond with the Cupressaceae and morphologically agree with the genus Cunninghamites.

There are three species of Cretaceous pines described in Cretaceous floras of the Northern Hemisphere having five needles per bundle. Pinus quinquefolia Hollick \& Jeffrey (1909, p. 16, pl. 22, fig. 2) from the Cretaceous of Raritan and Maghoty Formation, USA; P. pseudostrobifolia Ogura (1932) and P. hokkaidoensis Stockey \& Ueda (1986) from the Late Cretaceous of Hokkaido, Japan. They are described and based on anatomically preserved material and therefore difficult to be compared with $P$. landsbergensis. Similar needle arrangement to $P$. lands- bergensis was observed by Robinson (1977, p. 729, figs 6-11) in $P$. quinquefolia. Also arrangement of its sheaths of cataphylls (Robinson 1977, fig. 6) is similar and suggestive. $P$. quinquefolia differs little from $P$. landsbergensis in having more delicate dimensions of dwarf shoots and shorter needles than P. landsbergensis. P. pseudostrobifolia is described on the basis of only one poorly preserved specimen, which provides limited information for comparison as already stated by Stockey \& Ueda (1986). It differs in cuticle thickness. P. pseudostrobifolia shows thickly cutinised cells while $P$. landsbergensis has thin walled cells. Another five-needle species is $P$. hokkaidoensis, which differs from $P$. landsbergensis in having oval to elliptical ordinary cells while P. landsbergensis has rectangular cells.

Pinus quenstedtii described by Lesquereux (1874, pl. 3, figs 6,7 ) from the Dakota Formation, Kansas, USA, with the five needle fascicles and also the ovuliferous cone, might represent closely related taxon to $P$. landsbergensis. However, their comparison is difficult due to the poor preservation of the Dakota material.

Material described as $P$. quenstedtii from the Cretaceous of Greenland by Heer (1874, pl. 38, figs 1-4) was revised by Nathorst (1897). After his studies of its epidermal structure Nathorst (1897) proposed a name Pinites (Pityophyllum) lindstroemii (Nathorst 1897, pp. 40, 67, pl. 5, figs $13-15,18-31$, pl. 6 , figs 17,18 ) for this conifer reflecting its isolated taxonomic position.

Systematic position of $P$. landsbergensis provides interesting insights in the evolution of the whole genus and provides material for further discussions. It is widely accepted the genus Pinus is subdivided into two subgenera Pinus and Strobus (Little \& Critchfield 1969). Presence or absence of sheaths of cataphylls is used as a quite good character for distinguishing the above-mentioned subgenera. P. landsbergensis shows clearly well developed persistent sheaths of cataphylls and therefore can be assign with high probability to the subgenus Pinus. It is however interesting that all recent European pines of the subgenus show only two or thre needles per fascicle. The only group of living pines having persistent sheaths of cataphylls and five needles per fascicle are those from the subsection Ponderosae occurring in western North America and Mexico (Gernandt et al. 2005). Morphological comparison indicates P. montezumae (Fig. 3C) as one of the most similar species within the Ponderosae. Whang et al. (2001) listed number of epidermal characters, which could be used for distinguishing pine foliage. Particularly important are the following characters: length of ordinary cells, shape of stomatal apparatus, number of subsidiary cells, and number of ordinary cells running between two rows of stomata. From the pines described by Gernandt et al. (2005) $P$. montezumae appears to be the most similar to $P$. landsbergensis. It shows the same type of stomata (Fig. 3B), the 
same number of subsidiary cells. It only differs from $P$. landsbergensis in having 3-9 ordinary cells between two stomatal rows (Fig. 3D) instead of 10-11 as it is in $P$. landsbergensis. Another very similar pine is $P$. devoniana, which epidermis displays similar number of ordinary cells between stomatal rows (8-13) but differs in having short ordinary cells. There are more pines from Central America and Mexico similar to $P$. landsbergensis. $P$. douglasiana and $P$. lumholzii both differ in number of ordinary cells between stomatal rows (7-9, resp. 4-7).

Anatomical similarity provide further arguments for the assumption that $P$. landsbergensis belongs to the subsection Ponderosae. Its presence in Europe in mid Cretaceous indicates possibilities of evolution of the section Trifoliae (including the subsection Ponderosae) outside North America and their migration to North America during mid-Cretaceous. This timinig agrees with first occurrences of pines in the North America (from 85-90 My Robinson 1977, Axelrod 1986, Millar 1993). Therefore, it is probable that even the whole subgenus Pinus evolved in Eurasia as already suggested by Krupkin et al. (1996).

\section{Acknowledgements}

My thanks go to Boris Ekrt for his assistance in the field, Michal Kubajko for his help with sieving of the material and Martin Valent for his assistance with the digital microscope. This study was financially supported by the Ministry of Culture of the Czech Republic (DKRVO 2013/05, National Museum, 00023272).

\section{References}

AxElRod, D.I. 1986. Cenozoic history of some western American pines. Annals of the Missouri Botanical Garden 73(3), 565-641. DOI 10.2307/2399194

Bosma, H.F., Kunzmann, L., Kvaček, J. \& van KonijnenburGvan CitTert, J.H.A. 2012. Revision of the genus Cunninghamites (fossil conifers), with special reference to nomenclature, taxonomy and geological age. Review of Palaeobotany and Palynology 182, 20-31.

DOI 10.1016/j.revpalbo.2012.06.004

ČECH, S., KLein, V., KŘiž, J. \& VALEČKA, J. 1980. Revision of the Upper Cretaceous stratigraphy of the Bohemian Cretaceous Basin. Věstník Ústředního ústavu geologického 55(5), 277-296.

ENGELHARDT, H. 1891. Ueber Kreidepflanzen von Niederschöna. Sitzungsberichte und Abhandlungen der Naturforschenden Gesellschaft ISIS, Dresden 12, 79-105.

FARJon, A. 2005. Pines, drawings and descriptions of the genus Pinus. 235 pp. E.J. Brill, Dr. W. Backhuys, Leiden.

Farjon, A. \& Styles, B.T. 1997. Flora Neotropica Monograph 75. Pinus (Pinaceae). 291 pp. The New York Botanical Garden, New York.

GeINITZ, H.B. 1871-1875. Das Elbthalgebirge in Sachsen. Erster Theil. Der untere Quader. Zweiter Theil. Der mittlere und obere Quader. Palaeontographica - Beiträge zur Naturgeschichte der Vorwelt 20(1), 1-319; (2), 1-245.

Gernandt, D.S., López, G.G., García, S.O. \& Liston, A. 2005. Phylogeny and classification of Pinus. Taxon 54(1), 29-42. DOI 10.2307/25065300

van DER HAM, R.W.J.M., van KoniJnenbuRG-VAN CitTERT, J.H.A. \& VAN DER Burgh, J. 2001. Taxodiaceous conifers from the Maastrichtian type area (Late Cretaceous, NE Belgium, SE Netherlands). Review of Palaeobotany and Palynology 116, 233-250. DOI 10.1016/S0034-6667(01)00092-6

HeER, O. 1869. Beiträge zur Kreide-Flora, [Part 1] Flora von Moletein in Mähren. Neue Denkschriften der Algemeine schweizerischen Gesellschaft für die gessamten Naturwissenschaften [Nouveaux mémoires de la société helvétique des sciences naturelles] 23(2), 1-24.

HeER, O. 1874. Die Kreide-Flora der artischen Zone, gegründet auf die von den schwedischen Expeditionen von 1870 und 1872 in Grönland und Spitzbergen gesammelten Pflanzen. Kungliga Svenska Vetenskaps-akademiens Handlingar 12(6), $1-138$.

Hollick, A. \& Jefrey, E.C. 1909. Studies of Cretaceous coniferous remains from Kreischerville, N.Y. New York Botanical Garden, Memoirs 3, 1-76.

Knobloch, E. \& KvačEK, J. 1997. Bennettitalean and coniferalean (?) leaves from the Cretaceous (Cenomanian) of the Bohemian Massif, Central Europe. Cretaceous Research 18, 567-586. DOI 10.1006/cres.1997.0074

Krupkin, A.B., Liston, A. \& Strauss, S.H. 1996. Phylogenetic analysis of the hard pines (Pinus subgenus Pinus, Pinaceae) from chloroplast DNA restriction site analysis. American Journal of Botany 83(4), 489-498. DOI 10.2307/2446218

KvačEK, J. 1992a. Leaf and fruit compressions from the Bohemian Cenomanian, 301-304. In Kovar-Eder, J. (ed.) Palaeovegetational development in Europe and regions relevant to its palaeofloristic evolution, Proceedings of the Pan-European Palaeobotanical Conference, Vienna, 19-23 September 1991. Museum of Natural History, Vienna.

KvAČEK, J. 1992b. A new Cenomanian floral locality from Praha [Nová lokalita cenomanské flóry]. Časopis Národního muzea v Praze, Řada př́rodovědná 158(1-4), 42.

KvaČEK, J. 1997. Sphenolepis pecinovensis sp. nov. a new taxodiaceous conifer from the Bohemian Cenomanian. Mededeelingen van's Rijks Geologischen Dienst. Haarlem 58, 121-128.

KVAČEK, J. 2000a. Frenelopsis alata and its microsporangiate and ovuliferous reproductive structures from the Cenomanian of Bohemia (Czech Republic, Central Europe). Review of Palaeobotany and Palynology 112(1-3), 51-78.

DOI 10.1016/S0034-6667(00)00035-X

KvaČEK, J. 2000b. Two conifers (Taxodiaceae) of the Bohemian Cenomanian, Czech Republic, Central Europe. Acta Palaeobotanica, Supplement 2, 129-151.

KvaČEK, J. 2003. Foliage of a broad leaved conifer Dammarophyllum from the Cenomanian of Bohemia. Journal of the National Museum (Prague), Natural History Series 172(1-4), 13-20.

KvAČEK, J. 2007. The conifer Brachyphyllum squammosum from the Bohemian Cenomanian. Acta Palaeobotanica 47(1), 25-35. 
Lesquereux, L. 1874. Contributions to the fossil flora of the Western Territories, Part II. The Cretaceous Flora. United States Geological Survey of the Territories 6(2), 137-592.

Little, E.L. JR. \& Critchfield, W.B. 1969. Subdivisions of the Genus Pinus (Pines). U.S.D.A. Forest Service Miscellaneous Publication 1144, 1-51.

Lin, C., Huang, J., Wu, C., Hsu, C. \& Chaw, S. 2010. Comparative chloroplast genomics reveal the evolution of Pinaceae genera and subfamilies. Genome Biology and Evolution 2, 504-517. DOI 10.1093/gbe/evq036

LinNÉ, K. 1753. Species plantarum, exhibentes plantas rite cognitas, ad genera relatas, cum differentiis specificis, nominibus trivialibus selecti, locis natalibus, secundum systema sexuale digestas, Tomus I[II]. 1200 pp. Impensis Laurenti Salvii, Stockholm [Holmiae].

Liston, E.L., Robinson, W.A., Pinero, D. \& Alvarez-Buyala, E.R. 1999. Phylogenetics of Pinus (Pinaceae) based on nuclear ribosomal DNA internal transcribed spacer region sequences. Molecular Phylogenetics and Evolution 11, 95-109. DOI 10.1006/mpev.1998.0550

Millar, J. 1993. Impact of the Eocene on the evolution of Pinus L. Annals of the Missouri Botanical Garden 80, 471-498. DOI $10.2307 / 2399795$

NAthoRst, A.G. 1897. Zur mesozoischen Flora Spitzbergens gegründet auf die Sammlungen der schwedischen Expeditionen. Kungliga Svenska Vetenskaps-akademiens Handlingar 30(1), 1-77.

PacltovÁ, B. 1977. Cretaceous angiosperms of Bohemia - Central Europe. The Botanical Review 43(1), 128-142. DOI 10.1007/BF02860851

Price, R.A., Liston, A. \& Strauss, S.H. 1998. Phylogeny and systematics of Pinus, 49-68. In Richardson, D.M. (ed.) Ecology and Biogeography of Pinus. Cambridge University Press, Cambridge.

OGuRA, Y. 1932. On the structure and affinities of some Cretaceous plants from Hokaido, $2^{\text {nd }}$ contribution. Journal of the Faculty of Science Imperial University of Tokyo, section III, Botany 2(7), 455-483.

Robinson, C.R. 1977. Pinus triphylla and Pinus quinquefolia from Upper Cretaceous of Massachusetts. American Journal of Botany 64, 726-732. DOI 10.2307/2441725

Rothwell, G.W., Mapes, G., Stockey, R.A. \& Hilton, J. 2012. The seed cone Eathiestrobus gen. nov.: fossil evidence for a
Jurassic origin of Pinaceae. American Journal of Botany 99, 708-720. DOI 10.3732/ajb.1100595

Ryberg, P.E., Rothwell, G.W., Stockey, R.A., Hilton, J., MAPES, G. \& Riding, J.B. 2012. Reconsidering relationships among stem and crown group pinaceae: Oldest record of the genus Pinus from the early cretaceous of Yorkshire, United Kingdom. International Journal of Plant Sciences 173(8), 917-932. DOI 10.1086/667228

Stockey, R.A. \& UedA, Y. 1986. Permineralized pinaceous leaves from the Upper Cretaceous of Hokkaido. American Journal of Botany 73, 1155-1160. DOI 10.2307/2443794

UličnÝ, D., Kvaček, J., Svobodová, M. \& ŠpičÁková, L. 1997. High-frequence sea-level fluctuations and plant habitats in Cenomanian fluvial to estuarine successions: Pecínov quarry, Bohemia. Palaeogeography, Palaeoclimatology, Palaeoecology 136, 165-197. DOI 10.1016/S0031-0182(97)00033-3

Velenovský, J. 1885. Die Gymnospermen der Böhmischen Kreideformation. 34 pp. E. Greger, Prag.

Velenovský, J. 1887. Neue Beiträge zur Kenntnis der Pflanzen des böhmischen Cenomans. Sitzungsberichte der Königlichen Gesellschaft der Wissenschaften, Mathematisch-naturwissenschaftliche Klasse 1886, 633-645.

VelenovsKý, J. 1889. Květena Českého cenomanu. Rozpravy Královské České společnosti nauk 7(3), 1-75.

VelenovskÝ, J. \& VinikLár̆, L. 1926. Flora Cretaca Bohemiae I. 57 pp. Státní geologický ústav Československé republiky, Praha.

Velenovský, J. \& VinikLÁr̆, L. 1927a. Flora Cretaca Bohemiae II. 54 pp. Státní geologický ústav Československé republiky, Praha.

VelENOVSKÝ, J. \& ViniKLÁR̆, L. 1927b. Einer neuer Pinus-Zapfen aus der böhmischen Kreide. Palaeontologischen Zeitschrift 8(1), 220-223. DOI 10.1007/BF03160421

Velenovský, J. \& VinikLÁŘ, L. 1929. Flora Cretaca Bohemiae III. 33 pp. Státní geologický ústav Československé republiky, Praha.

Velenovský, J. \& VinikLÁR̆, L. 1931. Flora Cretaca Bohemiae IV. 112 pp. Státní geologický ústav Československé republiky, Praha.

Whang, S.S., PaK, J.-H., Hill, R.S. \& Kim, K. 2001. Cuticle micromorphology of leaves of Pinus (Pinaceae) from Mexico and Central America. Botanical Journal of the Linnean Society 135, 349-373. DOI 10.1111/j.1095-8339.2001.tb00787.x 